\title{
ОТ КАКОГО НАСЛЕДСТВА ОТКАЗЫВАЮТСЯ РОССИЙСКИЕ ЭЛИТЫ \\ (эволюция смысла Великой Отечественной войны во властном дискурсе)
}

\author{
А.В. Дука \\ (alexander-duka@yandex.ru) \\ Социологический институт РАН - филиал ФНИСЦ РАН, \\ Санкт-Петербург, Россия
}

Цитирование: Дука А.В. От какого наследства отказываются российские элиты (эволюция смысла Великой Отечественной войны во властном дискурсе) // Власть и элиты. 2020. Т. 7, № 2. С. 97-128.

DOI: https://doi.org/10.31119/pe.2020.7.2.5

Аннотация. Рассматривается производство смыслов Великой Отечественной войны властными группами Советского Союза и Российской Федерачии. Любая война предполагает определение врага и его квалификацию. Это и задает качественную определенность войне, делает ее политическим событием. Данная проиедура связана с определением смысла конкретной войны, что является важным политическим актом, способствующим легитимации режима и существования властных групп. Более того, осмысляя войну, властные группы и население включают ее в уже существующий смысловой мир. Элиты могут пытаться воздействовать на этот процесс. Но их возможности ограничены. Первоначальное определение Второй мировой войны как империалистической с вхождением в нее Советского Союза подверглось радикальному переосмыслению. Использование уже существовавшего с ХІХ в. наименования оборонительной войны как Отечественной помогло в осмыслении ее как общенародной и справедливой. Возвращение во властный политический дискурс данных смыслов наложилось на характеристику существовавщего режима, государственного устройства и экономического строя. Одновременно в советских и партийных документах, в выступлениях Сталина указывалась иель германской агрессии: уничтожение советского строя. И враг определялся соответствующим образом - немеикий фашизм. Тем самым уситивается тегитимаиия общественного и государственного строя. Одновременно произошло переопределение союзников, врагов, агрессоров. Англия и Франция из агрессоров превратились в союзников. По окончании войны мотивы преимущества социализма и советской власти в связи с победой 
становятся основными. Но с 1970-х годов обнаруживается постепенное изменение военного дискурса, что было связано с разрядкой напряженности. Прекращение существования СССР, главного победителя в Великой Отечественной войне, преврашает ее в прежде всего исторический бакт: нет соииалистического строя и советского государства, которые победили. Риторика о войне и смысл войны сильно трансформировались. Если главньй мотив в начале войны и в ее коние был отчетливо классовым, то в современной российском властном дискурсе он теряет этот советский стержень. Война предстает в большей мере как межгосударственная. В дискурсе о войне, в отличие от ее изначальной общенародности и борьбы с врагом, преобладает элемент жертвенности. Эти мотивы усиливаются появившимися новыми практиками, наиважнейшей из которьх является "Бессмертный полк». Происходит и переосмысление народа как победителя в войне. Соответственно и миссия в войне Советского Союза также трансформируется.

Ключевые слова: элиты, властные группь, смысл войны, Великая Отечественная война, властныци дискурс.

Притязание на сильную национальную историю влияет на легитимность и сплоченность государства. В неменьшей мере это относится к властным элитам, претендующим на правомерность занятия своих позиций и фактического владения государством. Война часто наиболее ярко, выпукло демонстрирует превосходство (даже если это только продукт смыслообразования властных групп). И в случае поражения, конвертируемого в моральное превосходство, связанного с жертвами и героической жертвенностью с «нашей» стороны и несправедливостью, коварством и жестокостью со стороны противника/врага, война остается важным источником легитимности ${ }^{1}$. Причем в этом случае определение и поиск врагов уже не является исключительной прерогативой политических инстанций. Здесь элиты и население действую в унисон.

Определение значения и смысла войны затрагивает вопрос о культурных основах функционирования элит. Элиты - хранители культурно-исторических смыслов. Но они и хранители своей власти, которая зиждется на определенном консенсусе с наиболее активной частью населения. В условиях кризиса и раскола элит, как мы видим, например, в современных США, приходится выбирать между альтернативными смыслами исторических событий. Но выбор делается и в более спокой-

1 Жертвы и страдания могут быть не только в связи с войной. См., например: [Ачкасов 2012: 137-138]. 
ной обстановке. Элиты постоянно маневрируют, даже внешне оставаясь приверженцами базовых фундаментальных исторических ценностей. Их маневры связаны с изменением обстоятельств их существования и функционирования, констелляций социальных групп внутри страны и внешней обстановкой. Соответственно ценностные ориентиры также трансформируются. Индикатором такой трансформации могут служить смыслы существенных исторических событий, которые иногда приобретают значение учредительных. Придание определенного смысла событию и внедрение его в публичное пространство и массовое сознание - важная работа элит и их окружения. Однако эта работа осуществляется вместе с подвластными. Можно попытаться радикально что-то переосмыслить, но без «предварительного согласия» основных групп населения, наиболее активно действующих в публичном пространстве, эта затея не удастся. Официальный дискурс может состояться, но быть при этом нелегитимным.

В истории государств значительное место занимают войны. Некоторые из них становятся (и по факту событийности, и по сложившимся представлениям) конституирующими в отношении общности событиями. К таким войнам для Советского Союза и Российской Федерации, безусловно, принадлежит Великая Отечественная война. Н.Е. Копосов по этому поводу пишет: «Миф о войне стал настоящим мифом происхождения постсоветской России» [Копосов 2011: 163].

\section{ПРОБЛЕМА СМЫСЛА ВОЙНЫ}

Война предполагает определение врага и его квалификацию. Собственно, это и задает качественную определенность любой войне и делает ее политическим событием. Героические схватки легендарных времен в меньшей степени могут быть охарактеризованы как политическое действие. Здесь индивидуальная удаль, рыцарский поединок выявляют персональную необычность. Но и в такого рода сюжетах встречаются важные характеристики враждебности и чуждости, против которых направлена сила и энергия героя. В качестве примера можно взять «Песнь о Роланде» (война с маврами), русские богатырские былины (борьба со степью). Против кого или чего и за кого или за что ведется война предполагает также и самоидентификацию создателя военного дискурса.

П.Л. Карабущенко, несколько преувеличивая, заметил: «Война - это среда существования политических элит» [Карабущенко 2015: 335]. 
С этим можно согласиться, но с поправкой. В той мере, в какой в процессе ее ставятся и решаются предельные вопросы существования больших общностей, в которых элиты играют существенные роли. И один из аспектов их ролевого поведения - создание, определение и навязывание смысла этого события, который должен стать обыденным, банальным, общепринятым суждением (доксой). Это предполагает дихотомичное представление социального и политического пространства: свое и враждебное, что соответствует самому характеру вооруженного противостояния. Одновременно происходит и моральное определение противостоящих сил: добро и зло. Вместе с тем в условиях военного противостояния возможна переквалификация участников конфликта, что связано с созданием коалиций, переходом тех или иных государств (правящих элит) на сторону бывших противников. Так, в 1965 г. в докладе Л.И. Брежнева, посвященном 20-летию победы советского народа в Великой Отечественной войне, было сказано: «Внесли свой вклад в разгром фашизма и болгарские, румынские, венгерские, финские войска» [Брежнев 1970: 138]. Но вооруженные силы этих стран достаточно долго активно воевали в союзе с Германией против Советского Союза, а некоторые их военные были непосредственными участниками уничтожения мирных советских граждан. Союзником может быть и принципиальный враг. Так, западные участники антигитлеровской коалиции все же характеризовались нашими руководителями в соответствии с классовым подходом как «наиболее реакционные империалисты» [Каганович 1996: 480]. Враг становится ситуативным.

Политическая конъюнктура может серьезно влиять на описание исторических событий и их осмысление. Но при этом для властных групп стоит задача стандартизации и нормализации политического языка. В процессе таких операций происходит возникновение и использование стандартных фраз и оборотов речи. Возникает политическая докса. Причем эти процедуры касаются не только подвластных групп и персон, но и внутриэлитных образований. «Докса и является тем культурным, или дискурсивным опосредованием, через которое осуществляется речь власти» [Барт 1989: 529]. Надо иметь в виду, что возможности по производству доксы со стороны элит все же ограничены. Существенен контекст, связанный с со-переживанием длящейся ситуации, единый для властных групп и подвластного населения. $\mathrm{OH}$ задает общие основания. «Смысл подобен сфере, куда я уже помещен, чтобы осуществлять возможные обозначения и даже придумывать их 
условия» [Делез 1995: 45]. Другое дело, что элиты, имеющие иной опыт и иные интенции, чем основная часть населения, стремятся объяснить и разъяснить существо переживаемого момента и сделать свои интерпретативные схемы само собой разумеющимися, служащими основанием осмысления мира и отдельных явлений, событий. Элиты нюансируют смысловую картину социального мира. И это иногда происходит в конфликте. П. Бурдье особо подчеркивает: «Докса установилась в результате борьбы между властвующими и подвластными, в ходе борьбы с оппозицией» [Бурдье 2016: 337].

Конечно, как отмечал Карл фон Клаузевиц, война - это политический акт [Клаузевиц 1936: 53-56]. Однако, вполне правомерно пишет Карл Шмитт, комментируя Клаузевица, военная борьба предполагает, «что уже имеется политическое решение о том, кто есть враг» [Шмитт 2016: 309]. Данное решение принимают суверенные инстанции, принадлежащие властным группам. В этом направлении размышляет и Хаймо Хофмайстер, критически анализируя Клаузевица. Война - это не политика, а выражение политического безвластия [Хофмайстер 2006: $100,104]$. Далее он пишет: «Война как разворачивание действий, подобно любым событиям, указывает на что-то большее, нежели она сама, поскольку те действия, из которых вытекают события, не являются для нее самоцелью, напротив, они направлены на нечто, что придает ее задаче целесообразный смысл» [Хофмайстер 2006: 102]. И этот смысл войны политичен. Но и сама война как инструмент политических инстанций задает характеристики политическому пространству. В ее отсутствии политические лидеры реализуют свои и общие интересы иначе. А без нее или ее угрозы многие задачи становятся невыполнимыми. И политическое безвластие относительное (во всяком случае пока политическим инстанциям удается держать в узде военные элиты). Собственно, здесь монополия на вооруженное насилие политических институтов и контролирующих их политических элит максимально проявляется. Хофмайстер показывает неоднозначность тезиса войны как инструмента политики, настаивая на существование у войны своей логики. И, скорее всего, это так. Но в контексте данного текста я центрирую свое внимание прежде всего на политике и политическом.

Вместе с тем важен характер войны, ее политико-правовая сторона. И здесь существенно, что в условиях середины XX в. появляется новый тип войны, в которой не признаются ограничивающие ее правила. Карл Шмитт дает ей следующую характеристику: «Война абсолютной вражды не ведает никакого оберегания. Последовательное осуществление 
абсолютной вражды придает войне ее смысл и справедливость» [Шмитт 2007: 82].

В России проблема войны рассматривалась с практической, теоретической и нравственной позиций. Важным для российской публики оказалось рассмотрение войны с точки зрения общечеловеческой истории, которое предложил В.С. Соловьев в 1899 г., и это вызвало большую дискуссию в обществе: «По-настоящему относительно войны следует ставить не один, а три различных вопроса: кроме общенравственной оценки войны есть другой вопрос - о ее значении в истории человечества, еще не кончивщейся, и, наконец, третий вопрос, личный - о том, как я, то есть всякий человек, признающий обязательность нравственных требований по совести и разуму, должен относиться теперь и здесь к факту войны и к тем условиям, которые из него практически вытекают? Смещение или же неправильное разделение этих трех вопросов общенравственного, или теоретического, затем исторического и, наконец, лично-нравственного, или практического, - составляют главную причину всех недоразумений и кривотолкований по поводу войны, особенно обильных в последнее время» [Соловьев 2012: 541]. Дальнейшие рассуждения приводят автора к пониманию амбивалентности войны с точки зрения здесь и сейчас существующих обстоятельств и резонов: «Смысл войны не исчерпывается ее отрицательным определением как зла и бедствия; в ней есть и нечто положительное - не в том смысле, чтобы она была сама по себе нормальна, а лишь в том, что она бывает реальной необходимою при данных условиях» [Соловьев 2012: 542]. За 22 года до Соловьева сходные мысли встречаются у Ф.М. Достоевского [Достоевский 1995: 116]. Война может иметь несколько смыслов, что зависит от наблюдателя и точки зрения.

Но здесь возникает проблема субъекта определения условий, обстоятельств, необходимости, оправданности войны. Прагматизм войны создает ее смысл, и в определенной мере снижает ее нравственную оценку. И даже может вывести ее в пространство имморального. Но для «простых» потребителей произведенных смыслов нравственные оценки сохраняются, пусть даже имплицитно. Очень показательно в этом отношении выступление И.В. Сталина на совещании начальствующего состава Красной Армии 17 апреля 1940 г. Оно достаточно откровенное и поучительное. Сталин ставит риторический вопрос и тут же на него содержательно отвечает: «Нельзя ли было обойтись без войны? Мне кажется, что нельзя было. Невозможно было обойтись без войны. Вой- 
на была необходима, так как мирные переговоры с Финляндией не дали результатов, а безопасность Ленинграда надо было обеспечить безусловно, ибо его безопасность есть безопасность нашего Отечества». Это что касается необходимости. Ну а обстоятельства также толкали к войне: «Было бы большой глупостью, политической близорукостью упустить момент и не попытаться поскорее, пока идет там война на Западе, поставить и решить вопрос о безопасности Ленинграда. Отсрочить это дело месяца на два означало бы отсрочить это дело лет на двадцать, потому что ведь всего не предусмотришь в политике. Воевать-то они там воюют, но война какая-то слабая: то ли воюют, то ли в карты играют. Вдруг они возьмут и помирятся, что не исключено. Стало быть, благоприятная обстановка для того, чтобы поставить вопрос об обороне Ленинграда и обеспечении безопасности государства, был бы упущен. Это было бы большой ошибкой» [Сталин 1997a: 347, 348]. Война здесь рассматривается как политико-техническая проблема за пределами моральных оценок. Хотя, слушатели понимают, что обеспечение нашей безопасности оправдывает агрессию, которая выступает лишь восстановлением справедливости путем установления справедливых границ. При этом сталинские рассуждения отрываются от «канонического» ленинского подхода с его дихотомией «справедливые - несправедливые войны» [История... 1938: 161].

И совершенно не связывается содержательно советско-финская война с войной на западе Европы. Это оказывается изолированным событием, не связанным с общим процессом пересмотра европейских границ и переделом европейского мира. И что важно, политико-идеологический аспект противостояния играет инструментально-подчиненную роль. «Перед финнами мы с начала войны поставили два вопроса - выбирайте из двух одно: либо идите на большие уступки, либо мы вас распылим, и вы получите правительство Куусинена, которое будет потрошить ваше правительство. Так мы сказали финской буржуазии. Они предпочли пойти на уступки, чтобы не было народного правительства» [Сталин 1997а: 351]. Но ведь и Советский Союз во главе с коммунистическим руководством пренебрег классовой солидарностью и революционной идеей. Хотя пропаганда внутри страны продолжала ориентировать граждан на пролетарский интернационализм и поддержку левых сил в Финляндии [Политический словарь 1940: 605-606]. Примечательно, что А.С. Черняев, после чтения дневника Георгия Димитрова заключил, что уже в 1938 г. стала очевидна тенден- 
ция в деятельности Сталина «стереть коммунистическое обличье в политике СССР» [Черняев 2010: 6].

Определение смысла конкретной войны - важный политический акт. Но как заметил Андре Конт-Спонвиль, «смысл настоящего никогда не присутствует в настоящем» [Конт-Спонвиль 2012: 549]. Он в прошлом или в будущем. В этом отношении смысл прошлых войн в их актуальности и возможной аналогичности. Так, наименование Первой мировой войны в дореволюционной России и зарубежной русской историографии Второй Отечественной подчеркивало оборонительный против западного нашествия характер. А также устанавливало связь с героическим прошлым, тем более что празднование столетия войны 1812 г. прошло совсем недавно.

Существует ее важный аспект, о котором писал А.А. Брусилов, народность. А отсюда и особое к ней отношение: «Я всегда исповедовал убеждение, что народная война - дело священное, которое военачальник должен вести, как бы священнодействуя, с чистыми руками и чистой душой, так как тут проливается человеческая кровь во имя нашей матери-родины» [Брусилов 2003: 153]. Помимо этого, в дискурсе о Первой мировой войне присутствовал мотив общего для всех дела: «Сверхнародный, сверхпартийный смысл настоящей войны, - вот что составляет силу России, славян и их союзников. Не будем же ослаблять себя какими-либо узкопартийными выступлениями и племенными распрями. Будем помнить, что в служении этому смыслу - наше главное превосходство над нашим врагом. Чтобы победить, нужно прежде всего сохранить этот смысл, который объединяет народы вокруг нашего знамени» [Трубецкой 1914b: 22-23].

Переименование Второй Отечественной войны в советской историографии и в политических текстах в империалистическую задавало отстраненный в отношении народа, трудящихся характер войны и порывало с несоциалистическим прошлым. Более того, она становится негероической и постыдной, так как результаты ее в случае победы связывались с аннексией чужой территории и контрибуциями.

Рассуждая о смысле (смыслах) войны, исследователи естественным образом опираются на тексты персон, находящихся у власти или при власти. О.Ю. Малинова указывает, что «широкая группа, которую было бы уместно назвать политическим классом» участвует в производстве и тиражировании смыслов [Малинова 2010: 200; Малинова 2011: 280]. Джон Цаллер эту группу называет элитой и указывает, что важ- 
нейшим аспектом ее деятельности является создание высокоизбирательного и стереотипизированного образа происходящих событий, потребляемого населением [Цаллер 2004: 40-41]. Это так, однако надо иметь в виду готовность населения потреблять смыслы. Смыслы не могут быть произвольным творчеством элит. Г.Л. Филд и Дж. Хигли писали, что границы поведения и установок элит определяются состоянием социальной организации, сознания и ориентаций не-элит [Field, Higley 1980]. Речь у авторов шла о социально-экономических характеристиках общества и основополагающих характеристиках поведения элит.

Представляется, что принцип базового соответствия общественного сознания и дискурса элит сохраняется при рассмотрении исторических макрособытий. Тем более что война, с тех пор как она исчезла, по словам Рене Жирара, «в качестве социального института в связи с изобретением воинской повинности, а затем и тотальной мобилизации» [Жирар 2019: 5], стала делом всех, а не только специальной социальной группы военных или определенного сословия. Также теряется кодификация: правила и регулярность более не сдерживают противников. Фон Мизес характеризует современные войны как тотальные - войны народов, в которых народ и армия едины [Мизес 2013: 141]. Стираются перегородки между правительством, армией и народом как объектами враждебных действий воюющих сторон [Кревельд 2011: 315-319]. Эта всеобщность войны ограничивает возможности элит по ее радикальному переосмыслению. Хотя нюансы остаются и сохраняется возможность корректировки массового сознания. Частично эта возможность основывается на этатизации войны [Фуко 2005: 65], значительного усиления и расширения сферы государства в виду новых военных задач [Жувенель 2011: 211-214], что, в свою очередь, дает элитам разнообразные ресурсы воздействия на общество. «Государство - главный производитель инструментов построения социальной реальности» [Бурдье 2016: 326]. Государство интегрирует когнитивные и оценочные структуры [Бурдье 2016: 329]. Здесь надо пояснить, что логика Жирара и Фуко, на которых я ссылаюсь, различна. Но каждый из них схватывает важные аспекты бытования войны, существенные для данных рассуждений. 


\section{ВЕЛИКАЯ ОТЕЧЕСТВЕННАЯ ВОЙНА В СОВЕТСКО-КОММУНИСТИЧЕСКОМ ДИСКУРСЕ}

На XVIII съезде ВКП(б) в марте 1939 г. И.В. Сталин констатировал возникновение новой империалистической войны за передел мира в Европе и Азии. В официальных текстах (включая словари) она получила название Второй империалистической войны. Началась она с вторжения Италии в Абиссинию в 1935 г., и, как отмечалось, «война, так незаметно подкравшаяся к народам, втянула в свою орбиту свыше пятисот миллионов населения, распространив сферу своего действия на громадную территорию - от Тяньцзина, Шанхая и Кантона через Абиссинию до Гибралтара» [Сталин 1997е: 295; Политический словарь 1940: 119]. Зачинщиками этой войны были Германия, Италия и Япония. Англия, Франция и США квалифицировались как «неагрессивные государства». Но уже через несколько месяцев, в ноябре 1939 г. И.В. Сталин в ответе редактору газеты «Правда» утверждал: «Не Германия напала на Францию и Англию, а Франция и Англия напали на Германию, взяв на себя ответственность за нынешнюю войну» [Сталин 1997d: 343; Политический словарь 1940: 120].

Такая быстрая смена официальной позиции и негативная характеристика всех участников империалистической войны приводила к дезориентации граждан и порождала некоторую отстраненность и восприятие событий в театральном или спортивном духе. Показательна в этом отношении запись в дневнике М.М. Пришвина от 11 июня 1940 г.: «Немцы подошли к Сене. Мне почему-то приятно, а Разумнику неприятно, и Ляля тоже перешла на его сторону. Разумник потому за французов (мне кажется), что они против нас, как в ту войну стоял за немцев - что они были против нас (хуже нас никого нет). А Ляля потому против немцев теперь, что они победители и ей жалко французов. Я же, как взнузданный, стоял за Гитлера» [Пришвин 2012: 188]. На следующий день он продолжает: «Пока немцы были в опасности и все говорили, что за Гитлера нельзя ставить карту, Ляля стояла в политике за немцев. Когда же немцы подошли к Парижу, то стала жалеть французов и одергивать меня, когда я радовался немецким победам» [Пришвин 2012: 189].

Превращение Второй империалистической войны в Великую Отечественную возвращало общенародный оборонительный и тем самым позитивный смыл (справедливая война и «ярость благородная»). Помимо упомянутых коннотаций, важно иметь в виду политико-идеоло- 
гический аспект. В «Директиве Совнаркома Союза ССР и ЦК ВКП(б) партийным и советским организациям прифронтовых областей» от 29 июня 1941 г. указывалась цель агрессии: «Целью этого нападения является уничтожение советского строя, захват советских земель, порабощение народов Советского Союза, ограбление нашей страны, захват нашего хлеба, нефти, восстановление власти помещиков и капиталистов» [Директива 1997: 52]. И враг определялся соответствующим образом - немецкий фашизм. В выступлении И.В. Сталина по радио 3 июля 1941 г. усиливается классовый, системный характер войны: враг «ставит своей целью восстановление власти помещиков, восстановление царизма, разрушение национальной культуры и национальной государственности русских, украинцев, белорусов, литовцев, латышей, эстонцев, узбеков, татар, молдаван, грузин, армян, азербайджанцев и других свободных народов Советского Союза, их онемечение, их превращение в рабов немецких князей и баронов» [Сталин 1997b: 59].

Намеренная архаизация задач «германского фашизма», приближение их к недавней борьбе за советскую власть и социализм превращала конкретного врага в экзистенциального. Тем самым усиливается легитимация общественного и государственного строя. И войне придается смысл «абсолютной вражды». Собственно, она таковой и была и со стороны нацистской Германии, и объективно.

Здесь можно привести в пример свидетельство современника в отношении немецкой пропаганды в начале войны (29 июля 1941 г.): «Читал германскую листовку, русскую и малограмотную, в которой говорилось, что “мы, немцы, вам никакого вреда не хотим, а только хотим избавить вас от жидов и коммунистов и поставить царя”. Полная бессмыслица!» [Пришвин 2012: 531] (также см.: [Шапорина 2017: 259]).

Смысл войны со стороны Советского Союза предстает как отрицание своего и навязываемого извне социально-исторического прошлого и устремление в прогрессивное будущее.

Вместе с тем в этой же речи происходит переквалификация Англии и Франции из стран-агрессоров, напавших на Германию и ведущих борьбу за колонии и за мировой господство. Сталин говорит о «верных союзниках» - народах Европы и Америки и «в том числе в лице германского народа, порабощенного гитлеровскими заправилами» [Сталин 1997b: 61]. Смысл войны расширяется: это освободительная война, являющаяся частью войны порабощенных народов «за их независимость, за демократические свободы» [Сталин 1997b: 61]. 
Идея освобождения других народов достаточно укорена в русском и российском политико-военном дискурсе, являясь частью политикокультурного мифа. Она присутствует в период войн с Наполеоном, в противостоянии с Турцией (особенно во второй половине XIX столетия). Во время Первой мировой войны (она же Вторая Отечественная) Е.Н. Трубецкой писал: «От победы немцев народы Европы могут ждать только поглощения и угнетения. Напротив, победа России и ее союзников, - если только нам суждено одержать ее, - прозвучит для всего мира благой вестью освобождения» [Трубецкой 1914а: 8]. Да и в современных рассуждениях политиков и аналитиков относительно российского участив в гражданской войне в Сирии эти мотивы играют не последнюю роль.

Сталин подчеркивает в своем выступлении, что мы не одиноки, мы на стороне добра и прогресса. Это весьма существенно, так как ориентировано на консолидацию не только сторонников социализма и советской власти, но и оппонентов, а возможно, и противников. Противник в данном случае не враг. Упоминание в тексте Черчилля и правительства США в этом отношении показательно.

Но общественное мнение оказалось расшатано от постоянной смены смыслов. И на первом этапе войны возникают разнообразные слухи. М.М. Пришвин фиксирует 11 октября 1941 г.: «Самая популярная политическая ориентация на болоте [село Усолье Ярославской обл., где Пришвин был в эвакуации] в настоящий момент - это что между Германией и Англией состоялось тайное решение о мире и разделе России» [Пришвин 2012: 629]. «В Ленинграде в сентябре ходили слухи о совещании в Москве с Америкой и Англией, они, дескать, требуют, чтобы Ленинград был сдан» [Шапорина 2017: 260]. Другие слухи фиксирует в декабре в Курской области Е.К. Герцык: «Американец Турцию занял и Закавказье», «Америка отступилась от нас» [Герцык 2007: 620, 621]. В апреле 1943 г. в Ленинграде прошел слух: «В Москве заседают англо-американцы, и Сталин сдает им в аренду Ленинград на 25 лет» [Шапорина 2017: 397]. Недоверие в искренность союзнических отношений [Шапорина 2017: 423] была скорее частью общего настроения и смыслового мира советских граждан.

Вместе с расширением круга друзей за счет капиталистических «боевых союзников» произошло и расширение задач войны. Через год руководитель советского государства определил: «Программа действия англо-советско-американской коалиции: уничтожение расовой исклю- 
чительности; равноправие наций и неприкосновенность их территорий; освобождение порабощенных наций и восстановление их суверенных прав; право каждой нации устраиваться по своему желанию; экономическая помощь потерпевшим нациям и содействие им в деле достижения их материального благополучия; восстановление демократических свобод; уничтожение гитлеровского режима» [Сталин 1997с: 124]. Программа вполне демократическая и является зеркальным отражением описанной ранее вождем в этом выступлении программы «итало-германской коалиции». Мы противоположны во всем. И поэтому мы с западными державами. Но мы также разделяем с ними многие ценности, за которые вместе воюем. Мы на стороне добра, воюющего против зла. Это в последующем породило некоторые иллюзии советских граждан относительно возможной эволюции советского режима.

По окончании войны мотивы преимущества социализма и советской власти в связи с победой становятся основными. В речи на предвыборном собрании избирателей Сталинского избирательного округа города Москвы 9 февраля 1946 г. (которую М.М. Пришвин охарактеризовал как «суровую»: «...и после такой-то войны, таких-то страданий, такой победы все те же пятилетки, все те же колхозы и гонка вооружения <...>. Ни одного ласкового слова хотя бы для детей» [Пришвин 2013: 45]) И.В. Сталин говорит о трех «субъектах» победы - общественный строй, государственный строй и вооруженные силы. Факторами, способствующими победе, подготовляющими, явились коллективизация и индустриализация.

Победа в войне стала основанием для важной генерализации: «Теперь речь идет о том, что советский общественный строй оказался более жизнеспособным и устойчивым, чем несоветский общественный строй, что советский общественный строй является лучшей формой организации общества, чем любой несоветский общественный строй» [Сталин 1997f: 8]. И это не только пропагандистское утверждение. Победа легитимирует победивший социализм (сохранение и укрепление «революционно-социалистической независимости», по словам Л.М. Кагановича [Каганович 1996: 479]) и утверждает его эффективность, очевидную для многих. Сформулированный Сталиным «структурноинституциональный триумвират победителей» существовал в отечественной политической риторике вплоть до конца советской власти. Соответственно и война прежде всего рассматривалась как борьба общественных систем. В общем-то это соответствовало и тотальному характеру «войны абсолютной вражды». 
Однако здесь есть нюансы. Победная триада была скорректирована. Через 20 лет после победы Генеральный секретарь так обозначил основных агентов победы: «советский народ, его славная героическая армия, руководимые ленинской партией коммунистов» [Брежнев 1970: 120]. Фактически главный организатор победы и победитель - Компартия. Отличие со сталинским дискурсом наблюдается и в обозначении факторов победы: «Общественная система социализма, ее экономические и организационные возможности, идейное и политическое единство советского общества, советский патриотизм и пролетарский интернационализм, дружба народов СССР, их сплоченность вокруг Коммунистической партии, беспримерный героизм и мужество Coветской Армии - вот главные факторы, определившие победу советского народа в Великой Отечественной войне» [Брежнев 1970: 128-129]. В это же время появляется важный мотив жертв, принесенных народом во время войны: «Гибель советских людей - наша самая тяжелая утрата» [Брежнев 1970: 128]. Частично это было связано, скорее всего, с новыми данными о человеческих потерях Советского Союза. Первоначальная цифра в 7 млн жизней увеличилась до более чем 20 млн. На праздновании 20-летней годовщины победы официально появились обновленные данные о потерях страны [Брежнев 1970: 128].

Но через восемь лет в речи Л.И. Брежнева 11 июля 1973 г. опять происходит корректировка: героический советский народ, Советское государство и великий социалистический строй выступают в качестве кузнецов победы [Брежнев 1974с: 196]. Конечно, армия упоминается, но она уже «зависимая переменная».

Вместе с тем коммунистические идеологические ориентиры при Л.И. Брежневе несколько ослабли, Realpolitik все больше проникает в советское внешнеполитическое взаимодействие с Западом. Визит президента США Р. Никсона «либеральной» и прагматической частью высших чиновников компартии воспринимался как «Рубикон всемирной истории». Заместитель заведующего Международным отделом ЦК КПСС А.С. Черняев отмечает в своем дневнике: «С этих майских недель 1972 г. будут датировать эру конвергенции» [Черняев 2010: 20]. В этом же году он делает следующую запись: «У нас идеология идет лишь на внутреннее потребление, т.е. там, где ее можно практически применить государственными средствами. И мы не такие дураки, чтоб заниматься идеологическими упражнениями в деловых, государственных отношениях с теми, кто спокойно может послать нас на...» [Чер- 
няев 2010: 25]. В следующем году, рассуждая о роли Л.И. Брежнева, он пишет: «Его заслуга в деле мира безусловна, а значит, и в общем повороте мирового развития к действительному сосуществованию, т.е. к совсем новой эпохе. В корне отличной от той, которая была прямым наследием Октября и войны» [Черняев 2010: 54]. После подписания Хельсинского заключительного акта в 1975 г. тональность изменилась и для внутреннего потребления. В беседе с Феликсом Чуевым 30 июня 1976 г. В.М. Молотов дал следующую характеристику внешней политики и государственной риторики: «Сейчас мы штаны сняли перед Западом. Получается, что основная цель не борьба с империализмом, а борьба за мир» [Чуев 1991: 109, 63]. Тем не менее в автобиографическом тексте Л.И. Брежнева 1981 г. «Чувство Родины» Великая Отечественная война характеризовалась как отстаивание великих завоеваний социализма [Брежнев 1981: 45].

\section{ВОЙНА В ПОСТСОВЕТСКОМ ОСМЫСЛЕНИИ}

Уолтер Липпман заметил: «Под влиянием пропаганды... старые константы нашего мышления стали переменными» [Липпман 2004: 240]. Прекращение существования СССР, непосредственного победителя в Великой Отечественной войне, превращает ее в прежде всего исторический факт: нет социалистического строя и советского государства, которые победили. Остались остатки армии, но уже с другими воинскими знаменами и эмблемами. И здесь обостряется борьба за историю и смысл войны: многое вдруг становится неочевидным.

Память о войне наиболее ярко способствует определению друзей и оппонентов / врагов здесь и сейчас. Кто за нашу память, а кто - против. Происходит осовременивание прошлого. Враг не тот, против кого мы сражались в войне, а тот, кто противостоит нам сейчас. В этом отношении показательны памятные мероприятия по поводу 80-летия начала Второй мировой войны в Польше.

Риторика о войне и смысл войны сильно трансформировались не только в Центральной и Западной Европе. В России изменения также прошли. Если главный мотив в начале войны и в ее конце был отчетливо классовым, то в современной российском властном дискурсе он теряет этот советский стержень. Война предстает в большей мере как война межгосударственная. Пропадает не только ее «межформационный» характер, но и «мировой», связанный с глобальным лидерством 
или принципами мироустройства. Одновременно подчеркивается народный характер войны в противопоставлении прежнему властному дискурсу. О.Ю. Малинова указывает, что первый президент РФ и его окружение пытались найти приемлемую для новой власти и ее идеологических установок интерпретацию Великой Отечественной войны. Единственный вразумительный результат: государство и режим не при чем, а победил народ [Малинова 2015: 100]. Причем уже не «советский». Победить уже существующий дискурс, ставший доксой, порождающий целый комплекс смыслов войны и победы, оказалось сложно. Тем более что новые властители сами были продуктом советской индоктринации. Лучшей тактикой властных элит в этих условиях оказалась минимизация суждений о войне и придания им большей абстрактности. Другой путь оказался бы политически затратным. Такого рода ситуацию описывает К.Ф. Завершинский: «Таким образом, “тропа зависимости” политических элит от динамики символических структур политической памяти, сопряженная с попытками их радикального переформатирования в процессе реализуемой элитами символической политики, стимулирует появления все новых маргинальных, ситуативных хронотопов жизнедеятельности и растущую конфронтацию идентификационных символических кодов политических сообществ» [Завершинский 2018: 455]. Задачей же властных групп первого буржуазного десятилетия России (особенно после малой гражданской войны 1993 г.) было минимизировать конфронтацию, тем более что контрэлиты были еще достаточно сильны и пользовались серьезной поддержкой в обществе.

Послеельцинское время характеризуется большей активностью элит по переосмыслению войны и Победы. Более того, Великая Отечественная война становится важным смыслоообразующим центром в попытках сконструировать идеологию новой России. В выступлении В.В. Путина в честь 70-летия Победы это отчетливо видно: «Наш народ сражался за свои святыни, за Родину, за свой дом, за культуру и родной язык, за нравственные и духовные ценности, за свободу Европы и за мир на планете и в этой праведной, священной борьбе с нацизмом не щадил себя, выстоял и победил!» [Путин 2015].

В этом отношении представляется релевантной типология войн Герфрида Мюнклера. В частности, он пишет: «На самом деле мировая война происходит лишь тогда, когда две державы или два союза борются за лидерство в глобальных масштабах либо когда в соперничестве 
крупных держав стоит вопрос о том, какие принципы и правила должны определять мировой порядок. Поэтому мировые войны представляют собой либо войны за полное или частичное мировое господство, либо битву за установление мирового порядка» [Мюнклер 2018: 103]. Война между нацизмом и советской системой и была борьбой за тот мировой порядок, который в соответствующих идеологиях предлагался, а элиты пытались реализовать. Это практическая реализация мессианства этих двух идеологий и миросозерцаний.

Почему началась война - проблема в наше время не столько историографическая, сколько политико-идеологическая. Обвинение Советского Союза со стороны геополитических противников строятся вокруг договора между Германией и СССР 23 августа 1939 г. В статье В.В. Путина «75 лет Великой Победы: общая ответственность перед историей и будущим», опубликованной 19 июня 2020 г. предлагается разделенная ответственность: «...нечестно утверждать, что двухдневный визит в Москву нацистского министра иностранных дел Риббентропа - главная причина, породившая Вторую мировую войну. Все ведущие страны в той или иной степени несут свою долю вины за ее начало. Каждая совершала непоправимые ошибки, самонадеянно полагая, что можно обхитрить других, обеспечить себе односторонние преимущества или остаться в стороне от надвигающейся мировой беды. И за такую недальновидность, за отказ от создания системы коллективной безопасности платить пришлось миллионами жизней, колоссальными утратами». Но выше в этом же тексте президент РФ указывает на ответственность западных стран: «Именно Мюнхенский сговор послужил тем спусковым крючком, после которого большая война в Европе стала неизбежной» [Путин 2020b]. Ошибки и попустительство агрессору. Проблема сводится к политико-дипломатическому взаимодействию. Дискурс империалистического передела мира и системного противостояния перестал быть актуальным.

Еще один аспект осмысления и презентации войны и победы в ней связан с причинами и факторами победы. Если в советской официальной историографии и в речах руководителей он отчетливо связан с системными характеристиками СССР, то при победившем капитализме приходится делать упор на других вещах. В статье В.В. Путина предлагается этнопсихологический и социопсихологический подход: «Как, почему смогли выстоять и победить? Откуда взялась их поистине железная сила духа, которая удивляла и восхищала весь мир? Да, они 
защищали свой дом, детей, близких, семью. Но всех объединяла любовь к Родине, к Отечеству. Это глубинное, личностное чувство во всей своей полноте отражено в самой сути нашего народа и стало одним из определяющих в его героической, жертвенной борьбе против нацистов». И ниже: «...в характере у народов России - исполнять свой долг, не жалеть себя, если того требуют обстоятельства. Самоотверженность, патриотизм, любовь к родному дому, к своей семье, к Отечеству - эти ценности и сегодня являются для российского общества фундаментальными, стержневыми. На них, по большому счету, во многом держится суверенитет нашей страны». И суждение в советских традициях: «Дружба народов, их взаимопомощь стали для врага настоящей несокрушимой крепостью» [Путин 2020b].

Существенно, что происходит и принципиальное переосмысление понятия «советский народ». Оно уже не связано с советским строем, а является просто совокупностью народов и граждан, проживавших на территории СССР: «Победа над нацизмом была одержана прежде всего советским народом... в этой героической борьбе - на фронте и в тылу, плечом к плечу - стояли представители всех республик Советского Союза» [Путин 2020b]. (Здесь примечательно, что предикат «советский» возвращается.) Это сближает с дореволюционным дискурсом. Е.Н. Трубецкой так представлял особенность войны в 1914 году: «[M]огучий подъем патриотического чувства, который объединяет в одно целое все народы великой империи, потому что в нем нет нацииональной исключительности, нет самообожания, нет того презрения и ненависти к другим народам, которые составляют характерную черту национализма. Никогда единство России не чувствовалось так сильно, как теперь, и, что всего замечательнее, нас объединила иель не узконациональная, а сверхнародная. В этом - причина тех симпатий, которые мы вызываем, в этом и источник нашей силы, в этом надежда на нашу победу» [Трубецкой 1914a: 7-8].

Разрыв со смысловой основой интерпретации войны проявляется не только в дискурсе властных персон. Значимым явлением представляется акция «Бессмертный полк». Здесь наглядно присутствует такая характеристика Отечественной войны как общенародность. Поэтому он быстро становится существенным элементом политики памяти и легитимации режима и входит в дискурс политической элиты. Но, в отличие от изначальной общенародности войны и борьбы с врагом, в нем преобладает элемент жертвенности. Эта акция скорее пассивна, 
чем активна. Это шествие в память погибших, отделенных от парада победителей. В этом ряду и бо́льшее обращение внимания на Холокост. В официальном дискурсе встречается тот же мотив: «...не меркнет память о прошедшей войне, о доблестных защитниках Родины, которые ценой неизмеримых жертв и утрат сокрушили нацизм» [Путин 2019b]; «их жизнь, испытания и жертвы, Победа, которую они передали нам, никогда не будут забыты» [Путин 2020b]. Контраст, разительный с дискурсом сталинского времени. В.М. Молотов вспоминал в 1979 г. как И.В. Сталин отреагировал на предложение включить в приказ о первом салюте по поводу освобождения городов Орла и Белгорода слова «Вечная память героям, павшим в боях». «Сталин прочитал и сказал: “Знаете, не память, а слава. Память звучит по-церковному. Вечная слава героям, павшим в боях за честь и независимость нашей Родины!” [Чуев 1991: 63].

Выше уже упоминалось о зачатках жертвенного осмысления войны в брежневский период. В речи на параде в честь 50-летия победы 9 мая 1995 г. Б.Н. Ельцин достаточно примечательно высказался: «Пусть сегодняшний день станет для всех нас днем поминовения погибших, днем единения сил добра» [Выступление... 1995]. При том что праздновалась победа. Важным этапом стал Указ Президента РФ от 8 июня 1996 г. «О Дне памяти и скорби». В нем говорится: «Двадцать второе июня 1941 года - одна из самых печальных дат в нашей истории, начало Великой Отечественной войны. Этот день напоминает нам о всех погибших, замученных в фашистской неволе, умерших в тылу от голода и лишений. Мы скорбим по всем, кто ценой своей жизни выполнил святой долг по защите Родины. Отдавая дань памяти жертвам Великой Отечественной войны 1941-1945 гг, а также жертвам всех войн за свободу и независимость нашего Отечества, постановляю: 1. Установить, что 22 июня - День памяти и скорби» [Указ Президента 1996]. О.Ю. Малинова интерпретирует этот акт как попытку уйти от советского идеологического наследия и одновременно уменьшит тему национальной славы и символически сблизить «братские» народы и страны - Белоруссию и Украину [Малинова 2015: 99].

Возможно, эти мотивы присутствовали. Обращение к жертвенности вполне закономерно в условиях отсутствия явной доминирующей идеологии. Примеры можно увидеть на Украине, в Польше, других странах, где национализм подогревается мифом трагедии, становящейся частью государственной идеологии. Событие же Великой Отечественной вой- 
ны и понесенные потери слишком значительны и фактически касаются почти каждой семьи, и таким образом идеологический вакуум заполняется. Вместе с тем необходимо сказать, что помимо Победы как позитивного символа окончания войны существует и понимание войны как травмы. Тем более что страна понесла громадные потери. Сопереживание травмы, так же как и победы, может иметь консолидирующую функцию, что не только знают, но и ощущают отечественные элиты. Причем травма войны предстает как многоаспектное событие, разрушившее экономику, пространства жизни, культурные ценности, уничтожившее и покалечившее миллионы людей. Травма страны и граждан. Поскольку нарратив потерь длительное время был тотальным, то и война воспринимается естественным образом как беда, сплачивающая всех без социальных границ. Джеффри Александер пишет, что статус травмы связан не столько с объективным характером происшедшего, сколько с его субъективным представлением о негативном влиянии на коллективную идентичность [Александер 2013: 273]. И это социокультурный процесс. Он утверждает: «Событие получает статус травмы, только если упорядоченные смыслы сообщества резко смещаются со своего привычного места» [Александер 2013: 274]. Но как быть с длительностью последствий события? На примере Холокоста социолог показывает воспроизводимость переживания травмы и специальные усилия (теоретиков, политиков, публицистов, гражданских активистов) по поддержанию статуса травмы и расширенной трансляции определенной интерпретации события. Коллективная идентичность в связи с трагическими событиями приобретает гражданский аспект и связывает знание и сопереживание с политическими ценностями сообщества.

В случае Великой Отечественной войны мы имеем схожую ситуацию. Дж. Александр указывает на то, что «у незападных народов разовьются драмы травмы, являющиеся функциональными эквивалентами Холокоста» [Александер 2013: 252]. Показательно в этом отношении интервью с Андреем Зайцевым, сценаристом и режиссером художественного кинофильма «Блокадный дневник», получившего главный приз Международного Московского кинофестиваля 2020 г. Он говорит: «Блокаду Ленинграда я ставлю в один ряд с Холокостом. Это одна из величайших трагедий в истории человечества. Одна из самых трагических осад, в которой погибло огромное количество людей, в страшных муках и страданиях. Причем людей сознательно убили голодом» [Нелюбин 2020]. Примечательно и первое судебное признание массо- 
вого убийства советских граждан в 1942 г. в Новгородской области геноцидом 27 октября 2020 г. [В России впервые... 2020]. Существенно, что нравственная оценка этих случаев носит универсальный характер. Также и суждения большинства членов российского элитного сообщества о гуманитарной трагедии войны стремятся к моральному универсализму. И смысл войны очевидно помещается в прошлое: это прошлое страдание.

\section{МИССИЯ ВОЙны}

В русском, советском и российском политическом дискурсе (впрочем, как и в иных национальных дискурсах) в рассуждениях о войне часто присутствует идея особой миссии. Об этом уже выше говорилось. Во время Первой мировой войны Е.Н. Трубецкой провозглашал: «Призвание России - бьть освободительницей народов. Оно навязывается ей силой исторической необходимости, ибо оно связано с кровными нашими национальными интересами. Мы твердо должны помнить, что победа может быть достигнута нами не одной только силой русского оружия. Она в значительной мере зависит от того, поверят ли народы в наше призвание» [Трубецкой 1914а: 9]. Этот пафос освобождения как важный элемент нравственного содержания войны подчеркивает справедливый характер противостояния с точки зрения России. Но в разные исторические периоды освобождение несло различную смысловую нагрузку.

Дискурс во время Великой Отечественной войны и долгое время после нее исходил из простых классовых посылок. Миссия - освободить и нести социализм. Это видно по многим текстам советских руководителей. Более того, Победа в войне обеспечила подъем национально-освободительного движения и крушение колониальной системы. Параллельно в 1970-х годах появляется важный мотив «спасения мировой цивилизации» и битвы «за грядущий справедливый мир», «основанной на уважении прав и интересов всех народов» [Брежнев 1974а].

Общегуманитарный смысл миссии подчеркивается и в статье B.В. Путина: «Красная Армия начала освободительную миссию в Европе, спасла от уничтожения и порабощения, от ужаса Холокоста целые народы. Спасла ценой сотен тысяч жизней советских солдат» [Путин 2020b]. Таким образом партикулярный классовый смысл заместился универсальным общечеловеческим. 


\section{ЗАКЛЮЧЕНИЕ}

За три четверти века официальное осмысление Великой Отечественной войны существенно изменилось. Властные группы Советского Союза и постсоветской России в формировании политической доксы (в разной степени успешности) символически используют Великую Отечественную войну и победу в ней. Однако их стратегии различны.

Для советско-коммунистического руководства смысл войны в борьбе общественных систем. Победа подтверждает прогрессивность социализма и легитимизирует миссию - освобождение человечества от буржуазно-империалистического гнета, а также объясняет воздействие победы на мировой процесс - освобождение колониальных народов, победа демократии и т.п.

После крушения советской власти элиты стремятся переформатировать культуру, переинтерпретировав войну. Смысл войны изменяется. В современном варианте осмысления войны она предстает прежде всего как борьба государств, т.е. сама по себе. Совершенно затушевывается политико-идеологический аспект. Идеология современных российских властных групп не пускает иные, чем либерально-буржуазные идеологические, конструкции в публичное пространство. Но собственного дискурса, в силу недолгой истории капиталистической России и присутствия значительной доли носителей старого советского дискурса, властные элиты не смогли создать. Вместе с тем начинает проявляться геополитический смысл: Европа во главе с Германией против России. Однако, если Л.И. Брежнев, говоря «Наш народ знает, что обе мировые войны пришли в его дом с Запада, из Европы. Мы помним 1941 год» [Брежнев 1974b: 76], имел в виду империалистическое нашествие, то для постсоветских элит, когда они становятся враждебными не по принципу идеологии, а по геополитическому и геоэкономическом основанию, требуется своей дискурс, свой смысл. Европа не капиталистическая, а культурно-цивилизационная. И здесь важно заявление В.В. Путина о России как отдельной уникальной цивилизации [Путин 2019а; 2020а]. То есть война начинает осмысляться как война цивилизаций и культур. Но войне в практической политике придается и важный смысл «независимой переменной». Имплицитно она призвана создать новую российскую общность на основе совместно переживаемой героической и трагической истории, вырабатывающими общую идентичность. 


\section{Литература}

Александер Дж. Смыслы социальной жизни: культурсоциология / пер. с англ. Г.К. Ольховникова; под ред. Д.Ю. Куракина. М.: Праксис, 2013. 640 с.

Ачкасов B.A. Роль политических и интеллектуальных элит посткоммунистических государств в производстве «политики памяти» // Символическая политика: сб. науч. тр. / отв. ред. О.Ю. Малинова. Вып. 1: Конструирование представлений о прошлом как властных ресурс. М.: ИНИОН РАН, 2012. C. $126-148$.

Барт Р. Разделение языков // Барт Р. Избранные работы: Семиотика. Поэтика / пер. с фр.; сост., общ. ред. и вступ. ст. Г.К. Косикова. М.: Прогресс, 1989. C. 519-534.

Брежнев Л.И. Великая победа советского народа. Доклад на торжественном собрании в Кремлевском Дворце съездов, посвященном 20-летию победы советского народа в Великой Отечественной войне, 8 мая 1965 года // Брежнев Л.И. Ленинским курсом. Речи и статьи. М.: Политиздат, 1970. Т. 1. С. 118-155.

Брежнев Л.И. Воспоминания: Жизнь по заводскому гудку. Чувство Родины. М.: Прогресс, 1981. 46 с.

Брежнев Л.И. (1974а) За справедливый демократический мир, за безопасность народов и международное сотрудничество. Речь в Кремлевском Дворце съездов на Всемирном конгрессе миролюбивых сил 26 октября 1973 года // Брежнев Л.И. Ленинским курсом. Речи и статьи. М.: Политиздат, 1974. Т. 4. С. 313-344.

Брежнев Л.И. (1974b) О пятидесятилетии Союза Советских Социалистических Республик. Доклад на совместном торжественном заседании Центрального Комитета КПСС, Верховного Совета СССР и Верховного Совета РСФСР в Кремлевском Дворце съездов 21 декабря 1972 года // Брежнев Л.И. Ленинским курсом. Речи и статьи. М.: Политиздат, 1974. Т. 4. С. 41-101.

Брежнев Л.И. (1974c) Речь в Большом Кремлевском дворце при получении Международной Ленинской премии «За укрепление мира между народами» 11 июля 1973 года // Брежнев Л.И. Ленинским курсом. Речи и статьи. М.: Политиздат, 1974. Т. 4. С.193-202.

Брусилов А.А. Мои воспоминания: Воспоминания. Мемуары. Минск: Харвест, 2003. $431 \mathrm{c}$.

Бурдье П. О государстве: курс лекций в Коллеж де Франс (1989-1992) / под ред. Патрика Шампаня [и др.]; пер. с фр. Д. Кралечкина и И. Кушнарёвой; предисл. А. Бикбова. М.: Дело, 2016. 720 с.

Гериык Е.К. Записки в оккупации // Герцык Е.К. Люди и образы / сост., авт. предисл. и коммент. Т.Н. Жуковская. М.: Молодая гвардия, 2007. С.611-630.

Делез Ж. Логика смысла / пер. с фр. Я.И. Свирского. М.: Академия, 1995. 298 с.

Директива Совнаркома Союза ССР и ЦК ВКП(б) партийным и советским организациям прифронтовых областей 29 июня 1941 года // Сталин И.В. Соч. М.: Писатель, 1997. Т. 15. С. 52-54. 
Достоевский Ф.М. Спасет ли пролитая кровь? (Дневник писателя. 1877. Апрель.) // Достоевский Ф.М. Собр. соч.: в 15 т. СПб.: Наука, 1995. Т. 14. C. $116-119$.

Жирар Р. Завершить Клаузевица: беседы с Бенуа Шантром / пер. с фр. А. Зыгмонта. М.: Изд-во ББИ, 2019. 300 с.

Жувенель Б. де. Власть: Естественная история ее возрастания / пер. с фр. В.П. Гайдамака и А.В. Матешук. М.: ИРИСЭН, Мысль, 2011. 546 с.

Завершинский К.Ф. Символические измерения социокультурной динамики современных политических элит // Власть и элиты. Т. 5 / отв. ред. А.В. Дука. СПб.: Интерсоцис, 2018. С. 438-460.

История Всесоюзной Коммунистической партии (большевиков): краткий курс: одобрен ЦК ВКП(б). 1938 г. М.: Госполитиздат, 1938. 352 с.

Каганович Л.М. Памятные записки рабочего, коммуниста-большевика, профсоюзного, партийного и советско-государственного работника. М.: Вагриус, 1996. 572 с.

Карабущенко П.Л. Элита и война: фальсификация побед и поражений // Каспийский регион: политика, экономика, культура. 2015. № 4 (45). С. 334-339.

Клаузевии К. О войне: в 2 т. / пер. с нем. А. Рачинского. 3-е изд. М.: Гос. воен. изд-во, 1936. Т. 1. 441 с.

Конт-Спонвиль А. Философский словарь / пер. с фр. Е.В. Головиной. М.: Этерна, 2012. 752 c.

Копосов Н.Е. Память строгого режима. История и политика в России. М.: Новое литературное обозрение, 2011. 315 с.

Кревельд М. ван. Расцвет и упадок государства / пер. с англ. под ред. Ю. Кузнецова и А. Макеева. М.: ИРИСЭН, Мысль, 2011. 544 с.

Липпман У. Общественное мнение. М.: Институт Фонда «Общественное мнение», 2004. 384 с.

Малинова О.Ю. Актуальное прошлое: символическая политика властвующей элиты и дилеммы российской идентичности. М.: Политическая энциклопедия, 2015. 207 с.

Малинова О.Ю. Политические элиты и производство смыслов в российской политике: к постановке проблемы // Мировой кризис и политические изменения. Политическая наука: ежегодник 2009 / отв. ред. А.И. Соловьев. М.: РОССПЭН, 2010. С. 200-211.

Малинова О.Ю. Политические элиты как «производители смыслов» российской политики: к постановке проблемы // Элиты и общество в сравнительном измерении: сб. ст. / под ред. О.В. Гаман-Голутвиной. М.: РОССПЭН, 2011. C. 280-293.

Мизес Л. фон. Всемогущее правительство: тотальное государство и тотальная война / пер. с англ. Б. С. Пинскер. М.; Челябинск: Социум, 2013. 456 с.

Мюнклер Г. Осколки войны: эволюция насилия в XX и XXI веках / пер. с нем. А.И. Лоскутовой. М.: Кучково поле, 2018. 384 с. 
Политический словарь / под ред. Г. Александрова, В. Гальянова и Н. Рубинштейна. М.: Госполитиздат, 1940. 672 с.

Пришвин М.М. Дневники. 1940-1941. М.: РОССПЭН, 2012. 880 с.

Пришвин М.М. Дневники. 1946-1947. М.: Новый Хронограф, 2013. 968 с.

Соловьев В.С. Оправдание добра / Отв. ред. О.А. Платонов. М.: Институт русской цивилизации, Алгоритм, 2012. 656 с.

Сталин И.В. (1997а) Выступление на совещании начальствующего состава Красной Армии 17 апреля 1940 года // Сталин И.В. Соч. М.: Писатель, 1997. T. 14. C. 347-360.

Сталин И.В. (1997b) Выступление по радио 3 июля 1941 года // Сталин И.В. Соч. М.: Писатель, 1997. Т. 15. С. 56-61.

Сталин И.В. (1997с) Доклад на торжественном заседании Московского Совета депутатов трудящихся с партийными и общественными организациями города Москвы 6 ноября 1942 года // Сталин И.В. Соч. М.: Писатель, 1997. T. 15. C. 117-128.

Сталин И.В. (1997d) Ответ редактору «Правды» 30 ноября 1939 года // Сталин И.В. Соч. М.: Писатель, 1997. Т. 14. С. 343.

Сталин И.В. (1997е) Отчетный доклад на XVIII съезде партии о работе ЦК ВКП(б) 10 марта 1939 года // Сталин И.В. Соч. М.: Писатель, 1997. Т. 14. С. 290-341.

Сталин И.В. (1997f) Речь на предвыборном собрании избирателей Сталинского избирательного округа города Москвы 9 февраля 1946 года // Сталин И.В. Соч. М.: Писатель, 1997. Т. 16. С. 5-16.

Трубеикой Е.Н. (1914а) Патриотизм против национализма // Трубецкой Е.Н. Смысл войны. Вып. 1. М.: тов-во тип. А.И. Мамонтова, 1914. С. 6-11.

Трубеикой Е.Н. (1914b) Смысл войны // Трубецкой Е.Н. Смысл войны. Вып. 1. М.: тов-во тип. А.И. Мамонтова, 1914. С. 17-23.

Фуко М. Нужно защищать общество: курс лекций, прочитанных в Коллеж де Франс в 1975-1976 учебном году / пер. с фр. Е.А. Самарской. СПб.: Наука, 2005. 312 c.

Хофмайстер Х. Воля к войне, или Бессилие политики. Философско-политический трактат / пер. с нем. и послесл. О.А. Коваль. СПб.: Гуманитарная Академия, 2006. 288 с.

Цаллер Дж. Происхождение и природа общественного мнения. М.: Ин-т Фонда «Общественное мнение», 2004. 559 с.

Черняев А.С. Совместный исход. Дневник двух эпох. 1972-1991 годы. М.: РОССПЭН, 2010. $1047 \mathrm{c}$.

Чуев Ф. Сто сорок бесед с Молотовым: Из дневника Ф. Чуева. М.: ТЕРРА, $1991.623 \mathrm{c}$.

Шапорина Л.В. Дневник: в 2 т. 3-е изд. М.: Новое лит. обозрение, 2017. Т. 1: [1898-1945]. 585 c.

Шмитт К. Понятие политического // Шмитт К. Понятие политического / пер. с нем. под ред. А.Ф. Филиппова. СПб.: Наука, 2016. С. 280-408. 
Шмитm К. Теория партизана. Промежуточное замечание к понятию политического / пер. с нем. Ю.Ю. Коринца. М.: Праксис, 2007. 301 с.

Field G.L., Higley J. Elitism. London; Boston: Routledge; Kegan Paul, 1980. $\mathrm{xi}+135 \mathrm{p}$.

\section{Источники}

В России впервые признали убийства нацистами советских граждан геноцидом // РИА Новости. 27.10.2020. URL: https://ria.ru/20201027/ genotsid-1581781036.html?utm_source=yxnews\&utm_medium=desktop (дата обращения: 27.10.2020).

Выступление президента РФ Б.Н. Ельцина на Красной площади на параде, посвященном 50-летию победы в Великой Отечественной войне 9 мая 1995 г. // Фонд «Президентский центр Б.Н. Ельцина» (Ельцин Центр). [Аудиофайл] URL: http://yeltsin.ru/archive/audio/64420/ (дата обращения: 23.10.2020).

Нелюбин Н. «Немцы окружили город. Стали уничтожать людей. Какие здесь могут быть ещё причины трагедии?»: Интервью с А. Зайцевым // Фонтанка.py. 21.10.2020. URL: https://www.fontanka.ru/2020/10/21/69512309/ (дата обращения: 21.10.2020.).

Путин В.В. Выступление на Торжественном приёме по случаю Дня Победы 9 мая 2015 г. // Сайт Президента РФ. URL: http://kremlin.ru/events/president/ news/49440 (дата обращения: 10.08.2020).

Путин В.В. (2019a) Выступление на итоговой пленарной сессии XVI заседания Международного дискуссионного клуба «Валдай» 3 октября 2019 года // Сайт Президента РФ. URL: http://kremlin.ru/events/president/news/61719 (дата обращения: 19.10.2019).

Путин В.В. (2019b) Выступление на Торжественном приёме по случаю Дня Победы 9 мая 2019 г. // Сайт Президента PФ. URL: http://kremlin.ru/events/ president/news/60493 (дата обращения: 10.08.2020).

Путин В.В. (2020а) Обращение к гражданам России 30 июня 2020 г. // Сайт Президента РФ. 30.06.2020. URL: http://kremlin.ru/events/president/news/63584 (дата обращения: 1.07.2020).

Путин В.В. (2020b) 75 лет Великой Победы: общая ответственность перед историей и будущим // Сайт Президента РФ. 19.06.2020. URL: http://kremlin. ru/events/president/news/63527 (дата обращения: 19.06.2020).

Указ Президента Российской Федерации от 08.06.1996 г. № 857 «О Дне памяти и скорби» // Сайт Президента РФ. URL: http://kremlin.ru/acts/bank/9515 (дата обращения: 20.10.2020). 


\section{WHAT INHERITANCE DO RUSSIAN ELITES REFUSE? (Evolution of the Meaning of the Great Patriotic War in the Power Discourse)}

\section{A. Duka}

(alexander-duka@yandex.ru)

Sociological Institute of the Russian Academy of Sciences a branch of the Federal Center of Theoretical and Applied Sociology of the Russian Academy of Sciences, St. Petersburg, Russia

Citation: Duka A. Ot kakogo nasledstva otkazyvayutsya rossiyskiye elity (evolyutsiya smysla Velikoy Otechestvennoy voyny vo vlastnom diskurse) [What inheritance do Russian elites refuse? (evolution of the meaning of the Great Patriotic War in the power discourse)]. Vlast' i elity [Power and Elites], 2020, 7 (2): 97-128. (In Russian)

DOI: https://doi.org/10.31119/pe.2020.7.2.5

Abstract. The article examines the production of the meanings of the Great Patriotic War by the power groups of the Soviet Union and the Russian Federation. Any war presupposes the definition of the enemy and his qualifications. This gives a qualitative definiteness to the war, makes it a political event. This procedure is associated with determining the meaning of a particular war, which is an important political act that contributes to the legitimization of the regime and the existence of power groups. Moreover, comprehending war, power groups and the population include it in the already existing semantic world. Elites may try to influence this process. But their options are limited. The original definition of World War II as imperialist with the entry of the Soviet Union into it has undergone a radical rethinking. The use of the name of the defensive war as Patriotic war, which has already existed since the 19th century, helped in understanding it as a nationwide and just one. The return to the imperious political discourse of these meanings was superimposed on the characteristics of the existing regime, state structure and economic system. At the same time, in Soviet and Communist party documents, in Stalin's speeches, the goal of German aggression was indicated: the destruction of the Soviet system. And the enemy was defined accordingly - German fascism. Thus, the legitimization of the social and state system is enhanced. At the same time, there was a redefinition of allies, enemies, aggressors. England and France turned from aggressors into allies. At the end of the war, the motives for the superiority of socialism and Soviet power in connection with victory become the main ones. But since the 1970s, there has been a gradual change in military discourse, which was associated with a Detente. The end of the existence of the 
USSR, the main winner in the Great Patriotic War, turns it into, first of all, a historical fact: there is no socialist system and the Soviet state, which won. The rhetoric of war and the meaning of war has been greatly transformed. If the main motive at the beginning of the war and at its end was clearly class, then in modern Russian power discourse it loses this Soviet core. The war appears to a greater extent as an interstate war. In the discourse about war, in contrast to the initial nationwide war and struggle with the enemy, the element of sacrifice prevails. These motives are reinforced by the emerging new practices, the most important of which is the "Immortal Regiment". There is also a rethinking of the "people" as a winner in the war. Accordingly, the mission in the war of the Soviet Union is also being transformed.

Keywords: elites, power groups, meaning of war, the Great Patriotic War, power discourse.

\section{References}

Achkasov V.A. Rol' politicheskih i intellectual'nyh elit postkommunisticheskiy gosudarstv v proizvodstve "poloitiki pamyati" [The role of political and intellectual elites of post-communist states in the production of "politics of memory"]. Simvolicheskaya politica [Symbolic politics]. Ed. by O.Yu. Malinova, vol. 1. Moscow: INION, 2012, pp. 126-148. (In Russian)

Alexander J. Smysly sotsial'noy zhizni: kultursotsiologiya [The meanings of social life. A cultural sociology]. Moscow: Praxis, 2013. 640 p. (In Russian)

Barthes R. Razdeleniye yazykov [Separation of languages]. Barthes R. Izbrannye raboty: Semiotika. Poetika [Selected works: Semiotics. Poetics]. Moscow: Progress, 1989, pp. 519-534. (In Russian)

Bourdieu P. O gosudarstve: kurs lektsiy v Kollezh de Frans (1989-1992) [On the State: a course of lectures at the College de France (1989-1992)]. Moscow: Delo, 2016. 720 p. (In Russian)

Brezhnev L.I. (1974a) Za spravedlivyy demokraticheskiy mir, za bezopasnost' narodov i mezhdunarodnoye sotrudnichestvo. Rech' v Kremlevskom Dvortse s"yezdov na Vsemirnom kongresse mirolyubivykh sil 26 oktyabrya 1973 goda [For a just democratic world, for the security of peoples and international cooperation. Speech at the Kremlin Palace of Congresses at the World Congress of Peace Forces on October 26, 1973]. In: Brezhnev L.I. Leninskim kursom. Rechi i stat'i [Lenin's course. Speeches and articles]. Vol. 4. Moscow: Politizdat, 1974, pp. 313-344. (In Russian)

Brezhnev L.I. (1974b) O pyatidesyatiletii Soyuza Sovetskikh Sotsialisticheskikh Respublik. Doklad na sovmestnom torzhestvennom zasedanii Tsentral'nogo Komiteta KPSS, Verkhovnogo Soveta SSSR i Verkhovnogo Soveta RSFSR v Kremlevskom Dvortse s'yezdov 21 dekabrya 1972 goda [On the fiftieth anniversary of the Union of Soviet Socialist Republics. Report at a joint solemn meeting of the Central Committee of the CPSU, the Supreme Soviet of the USSR and the Supreme Soviet of the RSFSR in the Kremlin Palace of Congresses on December 21, 1972]. In: 
Brezhnev L.I. Leninskim kursom. Rechi i stat'i [Lenin's course. Speeches and articles]. Vol.4. Moscow: Politizdat, 1974, pp. 41-101. (In Russian)

Brezhnev L.I. (1974c) Rech'v Bol'shom Kremlevskom dvortse pri poluchenii Mezhdunarodnoy Leninskoy premii «Za ukrepleniye mira mezhdu narodami» 11 iyulya 1973 goda [Speech at the Grand Kremlin Palace upon receiving the International Lenin Prize "For Strengthening Peace Among Nations" July 11, 1973]. In: Brezhnev L.I. Leninskim kursom. Rechi i stat'i [Lenin's course. Speeches and articles]. Vol. 4. Moscow: Politizdat, 1974, pp. 193-202.

Brezhnev L.I. Velikaya pobeda sovetskogo naroda. Doklad na torzhestvennom sobranii v Kremlevskom Dvortse s'yezdov, posvyashchennom 20-letiyu pobedy sovetskogo naroda v Velikoy Otechestvennoy voyne, 8 maya 1965 goda [Great victory for the Soviet people. Report at a solemn meeting in the Kremlin Palace of Congresses, dedicated to the 20th anniversary of the victory of the Soviet people in the Great Patriotic War, May 8, 1965]. In: Brezhnev L.I. Leninskim kursom. Rechi i stat'i [Lenin's course. Speeches and articles]. Vol. 1. Moscow: Politizdat, 1970, pp. 118-155. (In Russian)

Brezhnev L.I. Vospominaniya: Zhizn' po zavodskomu gudku; Chuvstvo Rodiny [Memories: Life on the factory dial tone; Sense of Homeland]. Moscow: Progress, 1981.

Brusilov A.A. Moi vospominaniya: Vospominaniya. Memuary [My Memories]. Minsk: Harvest, 2003. 431 p. (In Russian)

Celler J. Proiskhozhdeniye i priroda obshchestvennogo mneniya [The nature and origins of mass opinion]. Moscow: Fond "Obshchestvennoye mneniye", 2004. 559 p. (In Russian)

Chernyayev A.S. Sovmestnyy iskhod. Dnevnik dvukh epokh. 1972-1991 gody [Joint exodus. Diary of two eras. 1972-1991]. Moscow: ROSSPEN, 2010. 1047 p. (In Russian)

Chuyev F. Sto sorok besed s Molotovym: Iz dnevnika F. Chuyeva [One hundred forty conversations with Molotov: From the diary of F. Chuev]. Moscow: TERRA, 1991. 623 p. (In Russian)

Clausewitz K. O voyne [About war], in 2 vols. Vol. 1. Moscow: Gosvoyenizdat, 1936. 441 p. (In Russian)

Cont-Sponville A. Filosofskiy slovar' [Philosophical Dictionary]. Moscow: Eterna, 2012. 752 p. (In Russian)

Creveld M. van. Rastsvet $i$ upadok gosudarstva [The Rise and Decline of the State]. Moscow: IRISEN, Mysl', 2011. 544 p. (In Russian)

Deleuze G. Logika smysla [The Logic of Sense]. Moscow: Academia, 1995. 298 p. (In Russian)

Direktiva Sovnarkoma Soyuza SSR i TSK VKP(b) partiynym i sovetskim organizatsiyam prifrontovykh oblastey 29 iyunya 1941 goda [Directive of the Council of People's Commissars of the USSR and the Central Committee of the CPSU (b) to the party and Soviet organizations of the front-line regions on June 29, 1941]. In: Stalin I.V. Sochineniya [Works]. Vol.15. Moscow: Pisatel', 1997, pp. 52-54. (In Russian) 
Dostoyevskiy F.M. Spaset li prolitaya krov'? (Dnevnik pisatelya. 1877. Aprel') [Will the spilled blood save? (Diary of a writer. 1877. April)]. In: Dostoyevskiy F.M. Sobraniye sochineniy v 15 t. [Collected works in 15 volumes], Vol. 14. St. Petersburg: Nauka, 1995, pp. 116-119. (In Russian)

Field G.L., Higley J. Elitism. London; Boston: Routledge and Kegan Paul, 1980. $\mathrm{xi}+135 \mathrm{p}$.

Foucault M. Nuzhno zashchishchat' obshchestvo: Kurs lektsiy, prochitannykh v Kollezh de Frans v 1975-1976 uchebnom godu [Society must be defended: A course of lectures given at the College de France in the 1975-1976 academic year]. St. Petersburg: Nauka, 2005. 312 p. (In Russian)

Gertsyk Ye.K. Zapiski v okkupatsii [Notes in the occupation]. In: Gertsyk Ye.K. Lyudi i obrazy [People and images]. Moscow: Molodaya gvardiya, 2007, pp. 611-630. (In Russian)

Girard R. Zavershit' Klauzevitsa: besedy s Benoît Chantre [Achever Clausewitz (Entretiens avec Benoît Chantre)]. Moscow: BBI Publish., 2019. 300 p. (In Russian)

Hofmeister H. Volya $k$ voyne, ili Bessiliye politiki. Filosofsko-politicheskiy traktat [The Will to War, or the Powerlessness of Politics. Philosophical and political treatise]. St. Petersburg: Gumanitarnaya Akademiya, 2006. 288 p. (In Russian)

Istoriya Vsesoyuznoy Kommunisticheskoy partii (bol'shevikov): Kratkiy kurs: Odobren TSK VKP(b). 1938 g. [History of the All-Union Communist Party (Bolsheviks): Short course: Approved by the Central Committee of the All-Union CP (b). 1938]. Moscow: Gospolitizdat, 1938. 352 p. (In Russian)

Jouvenel B. de. Vlast': Yestestvennaya istoriya yeye vozrastaniya [Power: The Natural History of Its Growth]. Moscow: IRISEN, Mysl', 2011. 546 p. (In Russian)

Kaganovich L.M. Pamyatnyye zapiski rabochego, kommunista-bol'shevika, profsoyuznogo, partiynogo i sovetsko-gosudarstvennogo rabotnika [Memoirs of a worker, communist-Bolshevik, trade union, party and Soviet-state worker]. Moscow: Vagrius, 1996. 572 p. (In Russian)

Karabushchenko P.L. Elita i voyna: fal'sifikatsiya pobed i porazheniy [Elite and War: Falsification of Victories and Defeats], Kaspiyskiy region: politika, ekonomika, kul'tura [Caspian Region: Politics, Economics, Culture], 2015, 4, pp. 334-339. (In Russian)

Koposov N.Ye. Pamyat'strogogo rezhima. Istoriya i politika v Rossii [Strict regime memory. History and politics in Russia]. Moscow: Novoye literaturnoye obozreniye, 2011. 315 p.

Lippmann W. Obshchestvennoye mneniye [Public opinion]. Moscow: Fond "Obshchestvennoye mneniye", 2004. 384 p. (In Russian)

Malinova O.Yu. Aktual'noye proshloye: Simvolicheskaya politika vlastvuyushchey elity i dilemmy rossiyskoy identichnosti [Actual past: Symbolic politics of the ruling elite and the dilemmas of Russian identity]. Moscow: Politicheskaya entsiklopediya, 2015. 207 p. (In Russian) 
Malinova O.Yu. Politicheskiye elity i proizvodstvo smyslov v rossiyskoy politike: $\mathrm{k}$ postanovke problemy [Political Elites and the Production of Meanings in Russian Politics: Towards a Problem Statement]. In: Mirovoy krizis i politicheskiye izmeneniya. Politicheskaya nauka: Yezhegodnik 2009 [World Crisis and Political Changes. Political Science: Yearbook 2009]. Ed. by A.I. Solov'yev. Moscow: ROSSPEN, 2010, pp. 200211. (In Russian)

Malinova O.Yu. Politicheskiye elity kak «proizvoditeli smyslov» rossiyskoy politiki: k postanovke problemy [Political elites as "producers of meanings" of Russian politics: to the problem statement]. In: Elity i obshchestvo $v$ sravnitel'nom izmerenii [Elites and society in a comparative dimension: collection of articles]. Ed. by O.V. Gaman-Golutvina. Moscow: Rossiyskaya politicheskaya entsiklopediya (ROSSPEN), 2011, pp. 280-293. (In Russian)

Mises L. von. Vsemogushchee pravitel'stvo. Total'noyr gosudarstvo i total'naya voyna [Omnipotent Government. The rise of the total state and total war.] Moscow; Chelyabinsk: Sotsium, 2013. 456 p. (In Russian)

Politicheskiy slovar' [Political Dictionary]. Ed. by G. Aleksandrov, V. Gal'yanov i N. Rubinshteyn. Moscow: Gospolitizdat, 1940.672 p. (In Russian)

Prishvin M.M. Dnevniki. 1940-1941 [Diaries. 1940-1941]. Moscow: ROSSPEN, 2012. 880 p. (In Russian)

Prishvin M.M. Dnevniki. 1946-1947 [Diaries. 1946-1947]. Moscow: Novyy Khronograf, 2013. 968 p. (In Russian)

Schmitt C. Ponyatiye politicheskogo [The concept of the political]. In: Schmitt C. Ponyatiye politicheskogo [The concept of the political]. St. Petersburg: Nauka, 2016, pp. 280-408. (In Russian)

Schmitt C. Teoriya partizana. Promezhutochnoye zamechaniye k ponyatiyu politicheskogo [The theory of the partisan. Intermediate remark on the concept of the political]. Moscow: Praxis, 2007. 301 p. (In Russian)

Shaporina L.V. Dnevnik: in 2 vols. $3^{\text {nd }}$ ed. Moscow: Novoye lit. obozreniye, 2017. Vol. 1: [1898-1945]. 585 p. (In Russian)

Solov'yev V.S. Opravdaniye dobra [Justification of good]. Moscow: Institut russkoy tsivilizatsii, Algoritm, 2012. 656 p. (In Russian)

Stalin I.V. (1997a) Vystupleniye na soveshchanii nachal'stvuyushchego sostava Krasnoy Armii 17 aprelya 1940 goda [Speech at a meeting of the commanding staff of the Red Army on April 17, 1940]. In: Stalin I.V. Sochineniya [Works]. Vol. 14. Moscow: Pisatel', 1997, pp. 347-360. (In Russian)

Stalin I.V. (1997b) Vystupleniye po radio 3 iyulya 1941 goda [Radio speech on July 3, 1941]. In: Stalin I.V. Sochineniya [Works]. Vol. 15. Moscow: Pisatel', 1997, pp. 56-61. (In Russian)

Stalin I.V. (1997c) Doklad na torzhestvennom zasedanii Moskovskogo Soveta deputatov trudyashchikhsya s partiynymi i obshchestvennymi organizatsiyami goroda Moskvy 6 noyabrya 1942 goda [Report at a ceremonial meeting of the Moscow 
Council of Working People's Deputies with party and public organizations of the city of Moscow on November 6, 1942]. In: Stalin I.V. Sochineniya [Works]. Vol. 14. Moscow: Pisatel', 1997, p. 343. (In Russian)

Stalin I.V. (1997e) Otchetnyy doklad na XVIII s"yezde partii o rabote TSK VKP(b) 10 marta 1939 goda [Report on the work of the Central Committee of the All-Union Communist Party of Bolsheviks at the XVIII Party Congress on March 10, 1939]. In: Stalin I.V. Sochineniya [Works]. Vol. 14. Moscow: Pisatel', 1997, pp. 290-341. (In Russian)

Stalin I.V. (1997f) Rech' na predvybornom sobranii izbirateley Stalinskogo izbiratel'nogo okruga goroda Moskvy 9 fevralya 1946 goda [Speech at the pre-election meeting of voters of the Stalin electoral district of Moscow on February 9, 1946]. In: Stalin I.V. Sochineniya [Works]. Vol. 16. Moscow: Pisatel', 1997, pp. 5-16. (In Russian)

Trubetskoy Ye.N. (1914a) Patriotizm protiv natsionalizma [Patriotism against nationalism]. In: Trubetskoy Ye.N. Smysl voyny [The meaning of war]. Issue 1. Moscow: Tovarishchestvo tipografii A.I. Mamontova, 1914, pp. 6-11. (In Russian)

Trubetskoy Ye.N. (1914b) Smysl voyny [The meaning of war]. In: Trubetskoy Ye.N. Smysl voyny [The meaning of war]. Issue 1. Moscow: Tovarishchestvo tipografii A.I. Mamontova, 1914, pp. 17-23. (In Russian)

Zavershinskiy K. Simvolicheskiye izmereniya sotsiokulturnoy dinamiki somremennyh politicheskih elit [Symbolic dimensions of socio-cultural dynamics of contemporary political elites]. Vlast' $i$ elity [Power and Elites]. Vol. 5. Ed. by A. Duka. St. Petersburg: Intersotsis, 2018, pp. 438-460. (In Russian) 